\title{
Coupling a Boron Doped Diamond Anode with a Solid Polymer Electrolyte to Avoid the Addition of Supporting Electrolyte in Electrochemical Advanced Oxidation Processes
}

\author{
Davide Clematis, ${ }^{[a]}$ Jihen Abidi, ${ }^{[b]}$ Giacomo Cerisola, $^{[a]}$ and Marco Panizza* ${ }^{*[a]}$
}

The application of electrochemical technologies to wastewater treatment is limited by solution conductivity. In this paper, a solid polymer electrolyte Nafion ${ }^{\circledR}$ membrane has been used sandwiched between a boron doped diamond (BDD) anode and $\mathrm{Ti} / \mathrm{RuO}_{2}$ cathode meshes to treat Bismarck Brown $\mathrm{Y}$ (BBY) solutions with very low conductivity. BBY has been chosen as model compound to the system, and the influence of several process parameters has been investigated. During the experiments the evolution of chemical oxygen demand (COD), color removal and nitrogen compounds have been monitored. The performances were strongly related with applied current and stirring rate, changed in a range of $0.5-2 \mathrm{~A}$ and 200 and $850 \mathrm{rpm}$, respectively. Their increment leads to a decrease of oxidation time required to remove BBY completely. The effect of the presence of $\mathrm{Na}_{2} \mathrm{SO}_{4}$ ( 2 and $7 \mathrm{mM}$ ) as supporting electrolyte has been also evaluated. Results were compared with a removal treatment carried out with a conventional batch system, using a flow cell containing liquid supporting electrolyte $\left(\mathrm{Na}_{2} \mathrm{SO}_{4}\right)$. This comparison highlighted that the new cell setup is performing better in removing organic compounds, and thus, can be considered as effective process for the treatment of solutions with a low conductivity.

\section{Introduction}

Nowadays wastewater treatment plays a primary role both environmental protection and water recovery. Traditional approaches such as biological or physicochemical are the most used treatment but some problems, as the formation of sludge and the pollutants toxicity for some microorganisms employed, are not still overcome.

Electrochemical treatments, a particular Advanced Oxidation Processes (AOPs), ${ }^{[1-3]}$ are a possible solution which offer different advantages. Among them, a fundamental factor is represented by their ability to oxidize a wide range of organic pollutants (e.g. herbicides, ${ }^{[4]}$ drugs, $^{[5]}$ food industry, ${ }^{[6]}$ surfactants ${ }^{[7]}$ and dyes ${ }^{[8]}$ ) with high efficiency and low formation of exhausted materials. In the last decades, many AOPs have been investigated including photocatalysis, ${ }^{[9,10]}$ ozone oxidation, ${ }^{[11]}$ Fenton's reagent ${ }^{[12]}$ and electrochemical oxidation. ${ }^{[13-15]}$ In general, the electrochemical processes are complex systems and a large number of parameters affects the performance. The optimization of these systems requires a careful choice of the main parameters to investigate and to reduce operating costs, and a key role is covered by the

[a] Dr. D. Clematis, Prof. G. Cerisola, Prof. M. Panizza

Department of Civil, Chemical and Environmental Engineering

University of Genoa

Via Opera Pia 15, 16145 Genoa (I)

E-mail: marco.panizza@unige.it

[b] J. Abidi

Unité de recherche Toxicologie Microbiologie Environnementale et Santé Department

Institution Faculté des Sciences, Université de Sfax B.P. 1173,3038 Sfax, Tunisie

An invited contribution to a Special Collection dedicated to Trends in Synthetic Diamond for Electrochemical Applications solution conductivity. In fact, running costs are strongly dependent by this parameter because an increasing of conductivity reduces the voltage drop and the energy consumption. Nevertheless, some wastewaters (e.g. pharmaceutical industries, food industries and hospital wastewater) present a too low conductivity to be directly treated with electrochemical processes. ${ }^{[16]}$ To apply electrochemical oxidation to solution of this kind is necessary to add a supporting electrolyte. The introduction of a compound, such as a salt $\left(\mathrm{Na}_{2} \mathrm{SO}_{4}, \mathrm{NaHCO}_{3}\right)$, brings positive effects, among them drop in cell voltage and then a possible reduction in energy consumption, but introduce also some drawbacks. The first is the material cost, but also technical problems can show up. Recently Ma et al. ${ }^{[17]}$ reported that the addition of $\mathrm{Na}_{2} \mathrm{SO}_{4}$ for the treatment of wastewater with low conductivity leaded to a lower removal of total organic carbon (TOC), and then new cell setup are needed for the treatment of these wastewater matrices. A first proposal, to reduce the cell voltage and substitute the conventional tank, was the employment of microfluidic flow reactor as proposed in the last years. ${ }^{[18-19]}$ Another possible and interesting technological solution is the use of a solid polymer electrolyte, made by a solid thin film electrolyte between the cathode and the anode side. ${ }^{[20]}$ The presence of this membrane allows a current flux between electrodes with a low cell voltage even if the solution provides a low conductivity. This kind of system based on SPE is already used for electrochemical production of ozone, ${ }^{[21-22]}$ and can be a promising system for wastewater treatment.

Therefore, the idea behind the cell introduced above is to pair a solid membrane, which provides ionic conductivity, and electroactive electrode for oxidizing organic compounds. Among them boron doped diamond (BDD) is widely study for its excellent properties. ${ }^{[23-30]}$ In fact, it has wide potential window, high-oxygen-overvoltage anodes, inert surface with 
low surface adsorption properties and good corrosion stability also in aggressive environment. ${ }^{[31]}$ Furthermore, its effectiveness has been demonstrated to treat solutions containing many type of compound, as surfactants, ${ }^{[32]}$ herbicides, $^{[33]}$ antibiotic $^{[34]}$ and dyes. ${ }^{[35-38]}$ In most of the applications, strong oxidant power is provided by the electro-generation of hydroxyl radicals $\left({ }^{\circ} \mathrm{OH}\right)$ at BDD surface from water discharge as shown in Equation (1):

$\mathrm{H}_{2} \mathrm{O} \rightarrow{ }^{\cdot} \mathrm{OH}+\mathrm{H}^{+}+\mathrm{e}^{-}$

To test the performance of this cell a Nafion ${ }^{\circledast}$ membrane was used as solid polymer electrolyte to investigate the removal of Bismarck Brown Y (BBY), a dye widely used for biological and microbiological analysis, for which the electrochemical removal was not well investigated in literature to the best of author knowledge. The solid electrolyte was sandwiched with a BDD anode and $\mathrm{Ti} / \mathrm{RuO}_{2}$ cathode, and the effects of different parameters (i.e. applied current, stirring rate and conductivity) on color and chemical oxygen demand (COD) removal were discussed.

\section{Results and Discussion}

The UV-vis spectra, shown in Figure 1, describes the electrolysis of $100 \mathrm{mg} \mathrm{L}^{-1}$ of Bismarck Brown $\mathrm{Y}$ in distilled water with an applied current of $1 \mathrm{~A}$ at $20^{\circ} \mathrm{C}$. In the UV-spectra two bands are detected at $458 \mathrm{~nm}$ and $212 \mathrm{~nm}$, respectively. The first, in the visible region, is attributed to BBY concentration, while the latter regards the $\pi \rightarrow \pi^{*}$ transitions of the aromatic rings. Progressively the absorbance band decrease, becoming negligible after $1 \mathrm{~h}$ of electrochemical treatment. As described below differences among the removal rate of BBY $(458 \mathrm{~nm})$, aromatic compounds $(212 \mathrm{~nm}$ ) and COD indicate that during the process some intermediate are formed. Nevertheless, all the organic specie present were well oxidized to $\mathrm{CO}_{2}$ and water thanks to the hydroxyl radicals produced on the BDD surface as reported by Eq. 2. Figure 2 reports the evolution of BBY concentration as a function of time for experiments performed at at 0.5, 1.0 and 2.0 A. For all the three current values a high removal has been achieved, but the higher is the applied current the faster is the

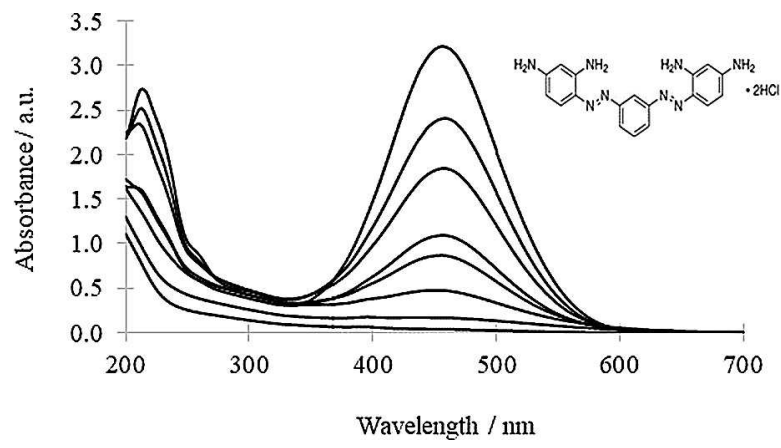

Figure 1. Evolution of the UV spectra as a function of time during treatment of $100 \mathrm{mg} \mathrm{L}^{-1}$ of BBY dissolved in double distilled water. Conditions: applied current: $2 \mathrm{~A}$; stirring rate $=850 \mathrm{rpm} ; \mathrm{T}=20^{\circ} \mathrm{C}$.

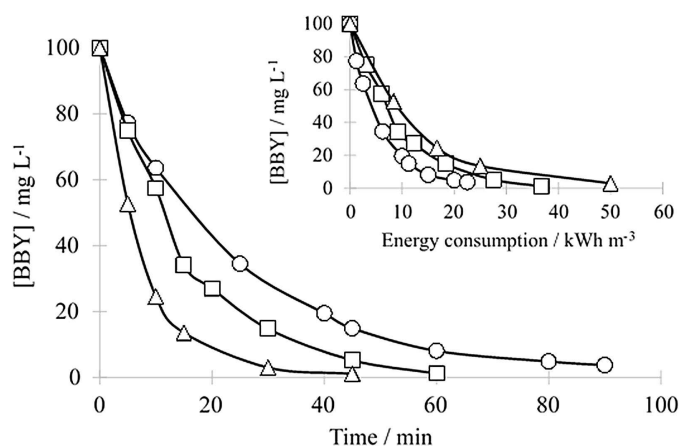

Figure 2. Influence of current density on the evolution of BBY concentration. Conditions: $\mathrm{BBY}$ initial concentration: $100 \mathrm{mg} \mathrm{L}^{-1}$ in distilled water; stirring rate $=850 \mathrm{rpm} ; \mathrm{T}=20^{\circ} \mathrm{C}$. The inset shows the BBY concentration as a function of energy consumption at different applied current: $0.5 \mathrm{~A}(\mathrm{O}), 1 \mathrm{~A}$ $(\square)$, and 2 A $(\Delta)$.

BBY removal, due to the higher generation of hydroxyl radicals from Eq. 2. To obtain the $97 \%$ of removal a time of 90,45 and 30 minutes is required for experiments performed at $0.5 \mathrm{~A}, 1 \mathrm{~A}$ and $2 \mathrm{~A}$, respectively. Nevertheless, from the inset of Figure 2, it is evident that increasing the current the specific energy consumption grows from $22.5 \mathrm{kWh} \mathrm{m}^{-3}$ operating with $0.5 \mathrm{~A}$ to $50 \mathrm{kWh} \mathrm{m}^{-3}$ at a current of $2 \mathrm{~A}$.

This increase in the energy consumption with current, can be ascribed to two main factors: (i) an enhancement of the cell potential and (ii) an activation of parasitic reaction of oxygen evolution [Eq. (2)].

$2 \mathrm{H}_{2} \mathrm{O} \rightarrow \mathrm{O}_{2}+4 \mathrm{H}^{+}+4 \mathrm{e}^{-}$

From these results a current value of $1 \mathrm{~A}$ is a possible compromise between time of removal and energy consumption.

Further information about the process were obtained by the experiments conducted applying a current of $1 \mathrm{~A}$ at different stirring rate, 200550 and $850 \mathrm{rpm}$, corresponding to a mass transfer coefficient km equal to $1.05 \times 10^{-5}, 1.43 \times 10^{-5}$ and $1.61 \times 10^{-5} \mathrm{~ms}^{-1}$, respectively. As shown in Figure 3, the

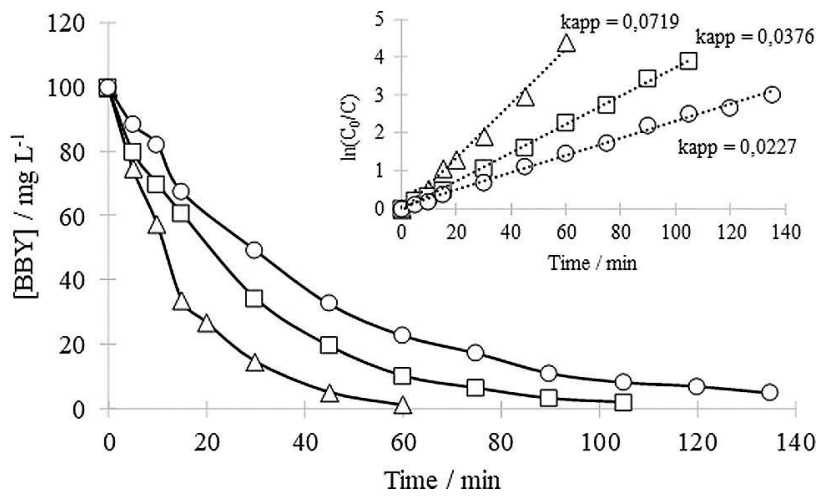

Figure 3. Influence of stirring rate on the evolution of BBY concentration. Conditions: $\mathrm{BBY}$ initial concentration: $100 \mathrm{mg} \mathrm{L}^{-1}$ in distilled water; applied current $=1 \mathrm{~A} ; \mathrm{T}=20^{\circ} \mathrm{C}$. The inset shows the kinetic analysis at different stirring rate: $200 \mathrm{rpm}(\bigcirc), 550 \mathrm{rpm}(\square \Delta)$, and $850 \mathrm{rpm}(\square)$. 
enhancement of this parameter leads to a faster removal of BBY and allow concluding that the process is under mass-transfer control. This means that the electron transfer is faster than the BBY transport and hence the oxidation of BBY is in competition with the secondary oxygen evolution reaction [Eq. (2)].

Within this stirring range all the removal process followed with a good agreement a pseudo-first order kinetic, described by an exponential decay of BBY concentration [Eq. (3)]:

$-\frac{d[B B Y]}{d t}=\mathrm{k}_{a p p} \cdot[\mathrm{BBY}]$

The results obtained by the integration of Equation (3) were reported in the inset of Figure 3 , and values for the kinetic constant $k_{a p p}$ were extrapolated in a range of $0.023 \mathrm{~min}^{-1}$ to $0.072 \mathrm{~min}^{-1}$.

In order to investigate the influence of the conductivity of solution on the removal of $B B Y$, several experiments were performed adding different amount of $\mathrm{Na}_{2} \mathrm{SO}_{4}$ in the range 2$7 \mathrm{mM}$. The presence of a supporting electrolyte decreases cell voltage (Table 1) but requires a higher time to remove the same amount of BBY (Figure 4). This behavior, summarized in Table 1, shows that to reach a pollutants removal of $97 \%$ the electrolysis time is $45 \mathrm{~min}$ and $120 \mathrm{~min}$ for the experiment conducted with distilled water and $6.62 \mathrm{mS} \mathrm{cm}^{-1}$ solution, respectively, causing a not acceptable rise of the energy consumption from 27.5 to $64.7 \mathrm{kWh} \mathrm{m}^{-3}$. A possible explanation about the worsening of process performance with the introduction of supporting electrolyte is the presence of sulphates,

Table 1. Influence of solution conductivity on cell voltage, time required to remove $97 \%$ of $\mathrm{BBY}$ and energy consumption.

\begin{tabular}{llll|} 
Test & $\begin{array}{l}\Delta \text { Vcell } \\
{[\mathrm{V}]}\end{array}$ & $\begin{array}{l}\text { Time[a] } \\
{[\mathrm{min}]}\end{array}$ & $\begin{array}{l}\text { Energy Consumption } \\
{\left[\mathrm{kWh} \mathrm{m}^{-3}\right]}\end{array}$ \\
\hline $\begin{array}{l}\text { Distilled } \\
\text { Water } \\
\mathrm{Na}_{2} \mathrm{SO}_{4}\end{array}$ & 11,35 & 45 & 27,5 \\
$\left(2 \mathrm{mM}^{2}\right.$ & 10,85 & 75 & 45,4 \\
$\mathrm{Na}_{2} \mathrm{SO}_{4}$ & 9,65 & 120 & 64,7 \\
$(7 \mathrm{mM})$ & & & \\
\hline [a] $97 \%$ removal. & &
\end{tabular}

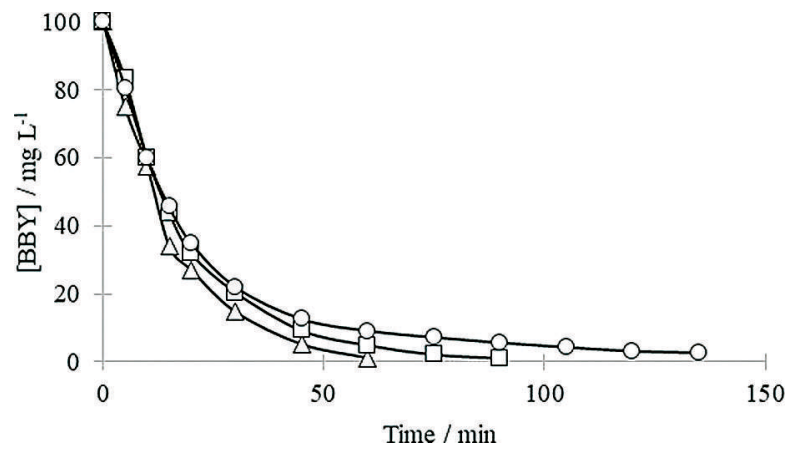

Figure 4. Influence of conductivity on the evolution of BBY concentration. Conditions: $\mathrm{BBY}$ initial concentration: $100 \mathrm{mg} \mathrm{L}^{-1}$; applied current $=1 \mathrm{~A}$; $\mathrm{T}=20^{\circ} \mathrm{C}$. Distilled water $(\square \Delta), \mathrm{Na}_{2} \mathrm{SO}_{4} 2.06 \mathrm{mS} \mathrm{cm}^{-1}$ ( $\left.\square\right), \mathrm{Na}_{2} \mathrm{SO}_{4} 6.62 \mathrm{mS} \mathrm{cm}^{-1}$ (○). which can react in the secondary reaction with the production of persulfate [Eq. (4)]:

$2 \mathrm{SO}_{4}{ }^{2-} \rightarrow \mathrm{S}_{2} \mathrm{O}_{8}{ }^{2-}+2 \mathrm{H}^{+}+2 \mathrm{e}^{-}$

The role of persulfate as oxidants is not clear and conflicting results were reported in literature. In fact, several authors highlighted beneficial effects about the presence of persulfate ions into the bulk solution, overcoming the mass-transfer limitation and then enhanced process efficiency. ${ }^{[39-41]}$ On the other hand, it was reported that under particular conditions, such for electrolysis performed at a current density higher than $8 \mathrm{~mA} \mathrm{~cm}^{-2}$ and with a sulphate concentration lower than $50 \mathrm{mM}$, the formation of persulfate leaded to a loss of performance. ${ }^{[42]}$ In the specific case considered here, selected operating conditions $\left(\left[\mathrm{Na}_{2} \mathrm{SO}_{4}\right]=2 \mathrm{mM}\right.$ or $7 \mathrm{mM}$ and $\left.\mathrm{i}=33 \mathrm{mAcm}^{-2}\right)$ are not favorable to obtain a positive effect on BBY removal. Another possible reason about the decreasing in performance is related with the operating temperature $\left(20^{\circ} \mathrm{C}\right)$ that penalizes $\mathrm{S}_{2} \mathrm{O}_{8}{ }^{2-}$ oxidation power if compare with those of hydroxyl radicals, leading to a decreasing of ${ }^{\circ} \mathrm{OH}$ concentration and then a worsening of removal rate. Nevertheless, a further addition of sulfate to obtain a positive effect is contrary to the purpose of this study, and more important is limited by Italian law (D. Lgs 152/06) that fixed an upper limit of $1000 \mathrm{mgL}^{-1}$ (10.4 mM) for sulfate.

To evaluate the SPE-based system effectiveness to operate with different pollutant loading, experiment with a lower or higher BBY concentration than $100 \mathrm{mg} \mathrm{L}^{-1}$ were performed as reported in Figure 5.

For all the BBY loading, electrochemical cell provided a complete removal but the higher is the concentration, the longer is the oxidation process, because of the presence of a greater quantity of BBY in solution. As expected from previous discussion, and reported in the inset of Figure 5, the process followed a first kinetic order reaction, and the kinetic rate constant trends pointed out that increasing the initial BBY concentration the reaction between hydroxyl radicals and subproducts took on a weight role if compare with the dye oxidation reactions.

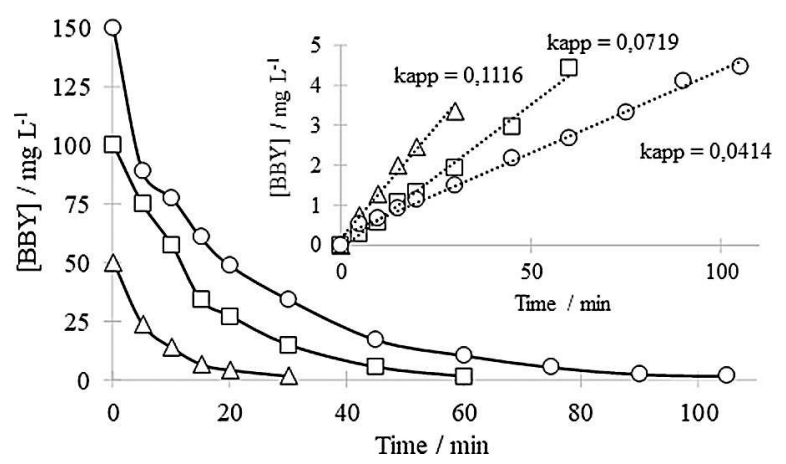

Figure 5. Influence of $B B Y$ concentration. Conditions: $I=1 \mathrm{~A}$; stirring rate $=850 \mathrm{rpm} ; \mathrm{T}=20^{\circ} \mathrm{C}$; Concentration: $50 \mathrm{mg} \mathrm{L}^{-1}(\square \Delta), 100 \mathrm{mg} \mathrm{L}^{-1}(\square)$, $150 \mathrm{mgL}^{-1}(\bigcirc)$. 
After discussing about the effects of these parameters, the best compromise between performance and costs is represented by intermediate current $(1 \mathrm{~A})$, high stirring rate $(850 \mathrm{rpm})$, low solution conductivity and avoiding the heating of solution. Taking into account these conditions as optimum, a COD analysis was made to evaluate also the byproducts removal (Figure 6). In fact, a complete removal of pollutant after 60 minutes does not indicate a completely removal of all organic compounds present in the solution. Doubling the time, a COD removal close to $93 \%$ was achieved pointing out that also BBY mineralization products were oxidized. The faster decrease of BBY concentration compared to the removal of COD indicated that some intermediates are produced during the oxidation. The evolution of these intermediated were obtained by the difference between COD and BBY concentration, and it increased in the first $50 \mathrm{~min}$ and then it progressively decreased up to zero. This time gap between BBY and COD removal is reflected also by energy consumption (Figure 6, inset), that increases from $36.3 \mathrm{kWh} \mathrm{m}^{-3}$ to completely degrade dye to $70 \mathrm{kWh} \mathrm{m}^{-3}$ to obtain the removal of $93 \%$ of initial COD.

During BBY electrolysis, the release of nitrogen was expected, and it can occur through different species. The possible formation of $\mathrm{NH}_{4}{ }^{+}, \mathrm{NO}_{2}^{-}$and $\mathrm{NO}_{3}{ }^{-}$was also monitored and the results are reported in Figure 7. During the process only, the formation of $\mathrm{NO}_{3}{ }^{-}$and $\mathrm{NH}_{4}{ }^{+}$was detected with a concentration of $0.03 \mathrm{mM}$ and $0.15 \mathrm{mM}$ after 2 hours of treatment, even if nitrates reached a stable value after 30 minutes and $\mathrm{NH}_{4}{ }^{+}$after 1 hour, that correspond to the time of dye removal. No nitrites and chloroamine were detected.

The results discussed above, obtained without the addition of supporting electrolyte in solution were compared with those obtained for BBY electrolysis carried out in a more conventional batch system, using a flow cell with parallel plate electrodes and containing liquid supporting electrolyte $\left(\mathrm{Na}_{2} \mathrm{SO}_{4}\right)$. Based on cell geometry and on the chosen flow rate $\left(200 \mathrm{Lh}^{-1}\right)$ a comparable mass transfer coefficient with those calculated for SPE system was obtained. From these assumptions, three experiments were carried out with two $\mathrm{Na}_{2} \mathrm{SO}_{4}$ concentration. The supporting electrolyte concentration used were $10 \mathrm{mM}$ (a

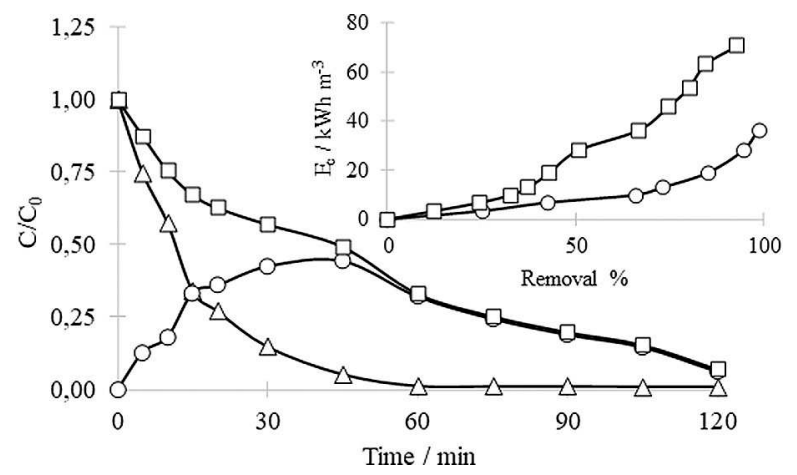

Figure 6. Trends of BBY $(\Delta)$, intermediates $(\square \bigcirc)$ and COD $(\square)$ concentration as a function of time. Inset: Inset: Evolution of energy consumptions for BBY $(\bigcirc)$ and $C O D(\square)$ removal. Conditions: $I=1 \mathrm{~A}$; stirring rate $=850 \mathrm{rpm}$; $\mathrm{T}=20^{\circ} \mathrm{C} ;[\mathrm{BBY}]$ concentration: $100 \mathrm{mg} \mathrm{L}^{-1}$.

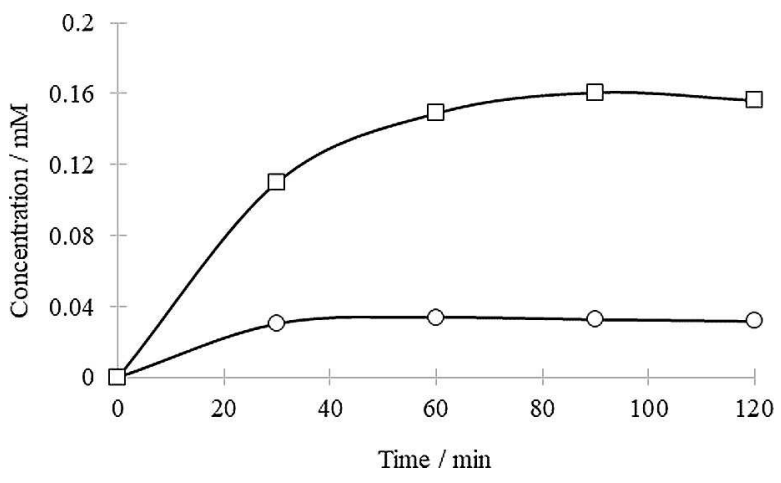

Figure 7. Evolution of concentration of $\mathrm{NH}_{4}{ }^{+}(\square)$ and $\mathrm{NO}_{3}{ }^{-}(\mathrm{O})$ during the treatment of $B B Y$ solution in distilled water. Conditions: $\mathrm{I}=1 \mathrm{~A}$; [BBY] $=100 \mathrm{mg} \mathrm{L}^{-1}$, stirring rate $=850 \mathrm{rpm} ; \mathrm{T}=20^{\circ} \mathrm{C}$.

lower value caused a too high cell voltage) and $20 \mathrm{mM}$ to have a cell voltage equal to the value obtained for the optimized experiment with solid electrolyte ( 11.4 V).

As reported in Figure 8 the BBY degradation in the flow cell with parallel plate electrodes was lower than in the SPE cell and for both concentration of $\mathrm{Na}_{2} \mathrm{SO}_{4}$, dye removal reached a plateau value of $89 \%$ after 60 minutes. Using the solid polymer electrolyte, the same electrolysis time allowed to obtain a complete removal of pollutant, confirming the suitability of this kind of systems. As regards energy consumption, after 1 hour of treatment energy consumption for two BDD setup cell are very close: 39.6 and $40.3 \mathrm{kWh} \mathrm{m}^{-3}$ for conventional BBD and SPE cell, respectively. Nevertheless, after 60 minutes the first one reaches a removal plateau at $87 \%$, while the new electrochemical cell allows obtaining a complete removal of pollutant.

\section{Conclusions}

The cell made by a solid polymer electrolyte membrane sandwiched between a $\mathrm{Ti} / \mathrm{RuO}_{2}$ cathode and $\mathrm{BDD}$ anode has been investigated to treat $\mathrm{BBY}$ solutions with low conductivity. The results showed that this system is able to completely

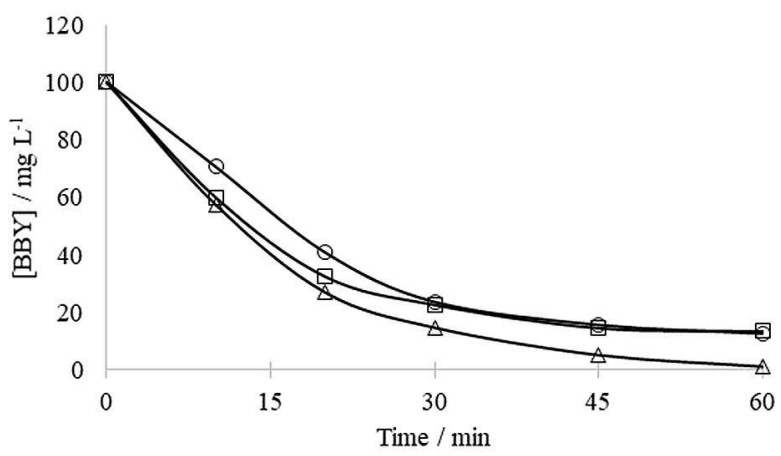

Figure 8. Comparison between BBY removal using SPE cell $(\Delta)$ and BDD anode in a batch system with flow cell in presence of supporting electrolyte $\mathrm{Na}_{2} \mathrm{SO}_{4} 10 \mathrm{mM}(\bigcirc)$ and $20 \mathrm{mM}(\square)$. Conditions: I $=1 \mathrm{~A}$; $[\mathrm{BBY}]=100 \mathrm{mg} \mathrm{L}^{-1}$; stirring rate $=850 \mathrm{rpm}$ (SPE system); Flow rate $=200 \mathrm{~L} \mathrm{~h}^{-1}$. 
oxidize the BBY content in 60 minutes and remove a high fraction of $C O D$, with the electrolysis of organic sub-products.

The influence of different parameters highlighted that the increase of applied current and stirring rate decrease the time required to obtain a complete removal of pollutant. An improvement of conductivity with the introduction of supporting electrolyte such as $\mathrm{Na}_{2} \mathrm{SO}_{4}$ decreased the cell voltage, but led to a longer oxidation time and more energy consumption. This worsening in performance are mainly due to the presence of persulfate and its weaker oxidant potential in used operating condition. Moreover, SPE system was able to operate properly in a pollutant concentration range between $50-150 \mathrm{mg} \mathrm{L}^{-1}$. A COD removal of $93 \%$ after 2 hours was obtained selecting the best electrolysis condition, nitrates and ammonia were detected, while was avoided the production of nitrites and chloroamine.

A further confirmation about the suitability of $\mathrm{Nafion}^{\circledR}$ membrane as solid electrolyte was confirmed by the comparison with a conventional electrolysis cell that required liquid supporting electrolyte. Therefore, the results confirm that this technology is promising for the treatment of wastewater with a low conductivity.

\section{Experimental Section}

The investigation of electrochemical oxidation of BBY was conducted in an open, cylindrical and undivided glass cell with a solution volume of $300 \mathrm{~mL}$. The solution was stirred using a magnetic stirrer and the rotation speed was changed between 200 and $850 \mathrm{rpm}$, and mass transfer coefficients were determined by limiting-current technique with the ferri/ferrocyanide couple. The cell had an anode/membrane/cathode structure with a Nafion ${ }^{\oplus}$ N324 membrane sandwiched between a Ni/BDD mesh anode and a $\mathrm{Ti} / \mathrm{RuO}_{2}$ mesh cathode as sketched in Figure 9.

The electrodes had dimensions of $3.5 \mathrm{~cm} \times 7.5 \mathrm{~cm}$ and spaced $0.15 \mathrm{~mm}$. The diamond electrodes are purchased from Condias, and has a diamond layer about $5 \mu \mathrm{m}$ and contains $3500 \mathrm{ppm}$ of boron deposited on a niobium substrate (thick $1.5 \mathrm{~mm}$ ) with six boreholes (diameter $4.5 \mathrm{~mm}$ ). Conventional batch system used as comparison was a flow cell with parallel plate electrodes and containing liquid supporting electrolyte $\left(\mathrm{Na}_{2} \mathrm{SO}_{4}\right)$. The electrodes were a BDD anode and stainless steel (AISI304) as cathode. Each electrode was square and had a geometric area of $30 \mathrm{~cm}^{2}$, with a electrode gap of $0.5 \mathrm{~cm}$.

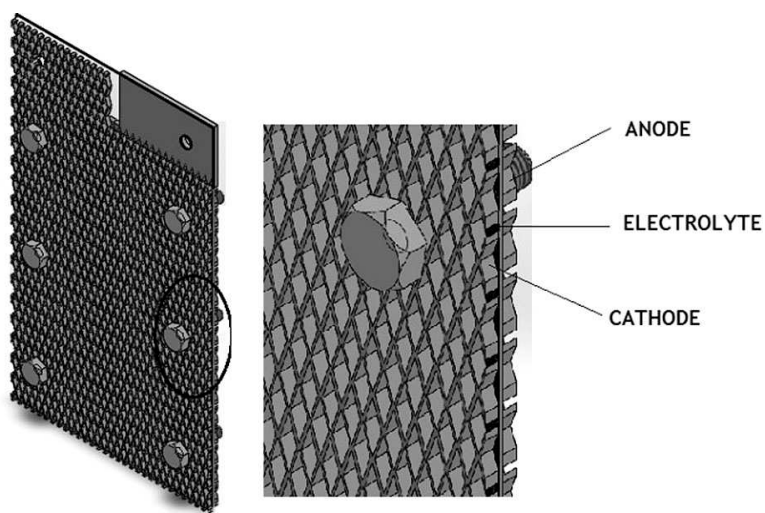

Figure 9. Solid polymer electrolyte cell.
The solution was recirculated with a flow-rate of $200 \mathrm{Lh}^{-1}$, corresponding to a mass-transfer coefficient of about $1.6 \times 10-$ $5 \mathrm{~ms}^{-1}$. Further details about this cell setup are reported elsewhere. ${ }^{[43]}$ The solutions were prepared by dissolving $\mathrm{BBY}$ $\left(\mathrm{C}_{18} \mathrm{H}_{18} \mathrm{~N}_{8} \cdot 2 \mathrm{HCl}\right.$ Sigma Aldrich) in double distilled water (conductivity $0.002 \mathrm{mS} \mathrm{cm}^{-1}$ ). In some experiences different amount of $\mathrm{Na}_{2} \mathrm{SO}_{4}$ (Sigma Aldrich, reagent grade $>99 \%$ ) were added to solution to study the effect of solution conductivity. The electrochemical oxidation was evaluated by UV-vis spectroscopy using a Jasco V630 spectrophotometer with cells with a $1 \mathrm{~cm}$ path length. The chemical oxygen demand (COD) of the solution, $\mathrm{NO}_{3}{ }^{-}$and $\mathrm{NH}_{4}{ }^{+}$ ions, were measured with Hach-Lange reagents set and a Dr. Lange LASA 3900 spectrophotometer. The energy consumption $\left(E_{c}\right.$ $\mathrm{kWh} \mathrm{m}^{-3}$ ) was calculated according to Equation (5):

$\mathrm{E}_{\mathrm{C}}=\frac{\mathrm{U}_{\text {cell }} \cdot \mathrm{l} \cdot \mathrm{t}}{3600 \cdot \mathrm{V}_{\mathrm{S}}}$

where $U_{\text {cell }}(V)$ is the average cell voltage, I the applied current $(A), t$ $(\mathrm{s})$ is the mineralization time and $\mathrm{V}_{\mathrm{s}}(\mathrm{L})$ the volume of treated solution.

\section{Conflict of Interest}

The authors declare no conflict of interest.

Keywords: boron-doped diamond · dyes · low conductivity solution · solid polymer electrolyte $\cdot$ waste prevention

[1] M. A. Oturan, J.-J. Aaron, Crit. Rev. Environ. Sci. Technol. 2014, 44, 25772641.

[2] I. Sires, E. Brillas, M. A. Oturan, M. A. Rodrigo, M. Panizza, Environ. Sci. Pollut. Res. Int. 2014, 21, 8336-8367.

[3] V. J. P. Vilar, C. C. Amorim, E. Brillas, G. L. Puma, S. Malato, D. D. Dionysiou, Environ. Sci. Pollut. Res. Int. 2017, 24, 5987-5990.

[4] A. R. F. Pipi, I. Sirés, A. R. De Andrade, E. Brillas, Chemosphere 2014, 109, 49-55.

[5] E. Brillas, I. Sirés, C. Arias, P. L. Cabot, F. Centellas, R. M. Rodríguez, J. A. Garrido, Chemosphere 2005, 58, 399-406.

[6] M. S. Melchiors, M. Piovesan, V. R. Becegato, V.A. Becegato, E. B. Tambourgi, A. T. Paulino, J. Environ. Manage. 2016, 182, 574-580.

[7] M. Panizza, D. Clematis, G. Cerisola, J. Environ. Chem. Eng. 2016, 4, 26922697.

[8] L. Labiadh, A. Barbucci, M. P. Carpanese, A. Gadri, S. Ammar, M. Panizza, J. Solid State Electrochem. 2017, 21, 2167-2175.

[9] S. Garcia-Segura, E. Brillas, J. Photochem. Photobiol. C 2017, 31, 1-35.

[10] G. Waldner, M. Pourmodjib, R. Bauer, M. Neumann-Spallart, Chemosphere 2003, 50, 989-998.

[11] M. Mehrjouei, S. Müller, D. Möller, Chem. Eng. J. 2015, 263, 209-219.

[12] C. A. Martínez-Huitle, E. Brillas, Appl. Catal. B 2009, 87, 105-145.

[13] C. A. Martínez-Huitle, M. A. Rodrigo, I. Sirés, O. Scialdone, Chem. Rev. 2015, 115, 13362-13407.

[14] M. Panizza, G. Cerisola, Chem. Rev. 2009, 109, 6541-6569.

[15] M. A. Rodrigo, N. Oturan, M. A. Oturan, Chem. Rev. 2014, 114, 87208745.

[16] G. Saracco, L. Solarino, R. Aigotti, V. Specchia, M. Maja, Electrochim. Acta 2000, 46, 373-380.

[17] P. Ma, H. Ma, S. Sabatino, A. Galia, O. Scialdone, Chem. Eng. J. 2018, 336, 133-140.

[18] J. F. Pérez, J. Llanos, C. Sáez, C. López, P. Cañizares, M. A. Rodrigo, Electrochem. Commun. 2017, 82, 85-88.

[19] O. Scialdone, C. Guarisco, A. Galia, Electrochim. Acta 2011, 58, 463-473.

[20] D. Clematis, G. Cerisola, M. Panizza, Electrochem. Commun. 2017, 75, 2124.

[21] Y. Cui, Y. Wang, B. Wang, H. Zhou, K.-Y. Chan, X.-Y. Li, J. Electrochem. Soc. 2009, 156, E75-E80. 
[22] Y. Honda, T. A. Ivandini, T. Watanabe, K. Murata, Y. Einaga, Diamond Relat. Mater. 2013, 40, 7-11.

[23] J. Zou, X. Peng, M. Li, Y. Xiong, B. Wang, F. Dong, B. Wang, Chemosphere 2017, 171, 332-338.

[24] N. Klidi, D. Clematis, M. Delucchi, A. Gadri, S. Ammar, M. Panizza, J. Electroanal. Chem. 2018, 815, 16-23.

[25] N. Klidi, D. Clematis, M. P. Carpanese, A. Gadri, S. Ammar, M. Panizza, Sep. Purif. Technol. 2018, 208, 178-183.

[26] S. Cotillas, D. Clematis, P. Cañizares, M. P. Carpanese, M. A. Rodrigo, M. Panizza, Chemosphere 2018, 199, 445-452.

[27] M. Panizza, G. Cerisola, Electrochim. Acta 2005, 51, 191-199.

[28] F. L. Souza, C. Saéz, M. R. V. Lanza, P. Cañizares, M. A. Rodrigo, Electrochim. Acta 2016, 187, 119-124.

[29] A. J. dos Santos, C. A. Martínez-Huitle, I. Sirés, E. Brillas, ChemElectroChem 2018, 5, 685-693.

[30] A. Kouskouki, E. Chatzisymeon, D. Mantzavinos, Z. Frontistis, ChemElectroChem 2008, 5, 1-8.

[31] A. Suzuki, T. A. Ivandini, K. Yoshimi, A. Fujishima, G. Oyama, T. Nakazato, N. Hattori, S. Kitazawa, Y. Einaga, Anal. Chem. 2007, 79, 8608-8615.

[32] B. Louhichi, M. F. Ahmadi, N. Bensalah, A. Gadri, M. A. Rodrigo, J. Hazard. Mater. 2008, 158, 430-437.

[33] S. A. Alves, T. C. R. Ferreira, N. S. Sabatini, A.C.A. Trientini, F. L. Migliorini, M. R. Baldan, N. G. Ferreira, M. R. V. Lanza, Chemosphere 2012, 88, 155-160.

[34] F. Sopaj, M. A. Rodrigo, N. Oturan, F. I. Podvorica, J. Pinson, M. A. Oturan, Chem. Eng. J. 2015, 262, 286-294.
[35] A. M. S. Solano, C. A. Martínez-Huitle, S. Garcia-Segura, A. El-Ghenymy, E. Brillas, Electrochim. Acta 2016, 197, 210-220.

[36] C. A. Martínez-Huitle, E. Brillas, Angew. Chem. Int. Ed. 2008, 47, 19982005; Angew. Chem. 2008, 120, 2024-2032

[37] C. A. Martínez-Huitle, M. Panizza, Curr. Opin. Electrochem. 2018, 11, 6271.

[38] A. N. Subba Rao, V. T. Venkatarangiah, Environ. Sci. Pollut. Res. Int. 2014, 21, 3197-3217.

[39] C. A. Martínez-Huitle, E. V. dos Santos, D. M. de Araújo, M. Panizza, J. Electroanal. Chem. 2012, 674, 103-107.

[40] M. Panizza, P. A. Michaud, G. Cerisola, C. Comninellis, J. Electroanal. Chem. 2001, 507, 206-214.

[41] D. M. Araújo, C. Sáez, C. A. Martínez-Huitle, P. Cañizares, M. A. Rodrigo, Appl. Catal. B 2015, 166, 454-459.

[42] C. Zhang, Z. He, J. Wu, D. Fu , J. Electrochem. Soc. 2015, 162, E85-E89.

[43] S. C. Elaoud, M. Panizza, G. Cerisola, T. Mhiri, Desalination 2011, 272, 148-153.

Manuscript received: November 27, 2018

Revised manuscript received: January 7, 2019

Accepted manuscript online: January 10, 2019

Version of record online: 


\section{ARTICLES}
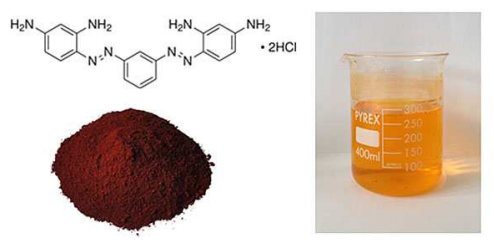

Garbage in, clean water out: A solid polymer electrolyte Nafion ${ }^{\circledast}$ membrane is used sandwiched between a boron doped diamond (BDD) anode and $\mathrm{Ti} / \mathrm{RuO}_{2}$ cathode meshes to treat solutions with very low conductivity containing Bismarck

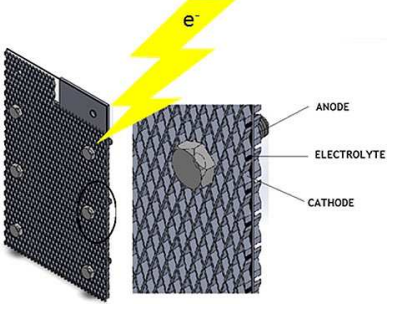

Brown Y (BBY) as model compound for waste water treatment. The new cell setup is performing good in removing organic compounds, and thus, can be considered as effective process for the treatment of solutions with a low conductivity.
Dr. D. Clematis, J. Abidi, Prof. G. Cerisola, Prof. M. Panizza*

$1-7$

Coupling a Boron Doped Diamond Anode with a Solid Polymer Electrolyte to Avoid the Addition of Supporting Electrolyte in Electrochemical Advanced Oxidation Processes 